Literatura y Lingüística $\mathrm{N}^{\circ} 26$

ISSN 0716-5811/ pp. 135-142

\title{
Gregorio Martínez, cronista de otra historia
}

\author{
Alejandra Huespe*
}

\section{Resumen}

Los mitos fundamentales de la conquista de América se sostuvieron sobre una idea de base: la existencia de una región fabulosa situada sobre la franja equinoccial. La necesidad de hallar oro en esas regiones ignotas marcó un impulso fundamental en el proceso de conquista y constituyó uno de los móviles más fuertes, sino tal vez el más importante. A partir del concepto ficciones de archivo que propone Roberto González Echevarría (2000), el presente trabajo aborda la forma en que se actualizan los mitos de la conquista en la obra literaria Crónica de músicos y diablos (1985) del escritor peruano Gregorio Martínez (Nasca, 1942).

Palabras clave: mito, conquista de América, ficciones de archivo, Gregorio Martínez.

\section{Gregorio Martínez, chronicler ot another history}

\section{Abstract}

The fundamental myths of the conquest of America were based upon one fundamental principle: the existence of a region located on the fabulous equator strip. The need to find gold in those unknown regions was a major boost in the process of conquest and was one of the strongest motives, and perhaps the most important one. Based on the concept ficciones de archivo proposed by Roberto Gonzalez Echevarría (2000), this paper addresses how myths of conquest are updated in Crónica de músicos y diablos (1985) written by Gregorio Martinez (Nasca, 1942).

Key Words: Myth, American Conquest, ficciones de archivo, Gregorio Martínez

Recibido: 26-01-2012 Aceptado: 27-06-2012

* Profesora en Letras. Investigadora del Instituto Interdisciplinario de Estudios Latinoamericanos, Facultad de Filosofía y Letras, Universidad Nacional de Tucumán-Argentina.

alejandrahuespe@hotmail.com 
Gregorio Martínez, cronista de otra historia / Alejandra Huespe

No importa si el mundo es concebido como real o solamente imaginado; la manera de darle sentido es la misma.

Hyden White, El texto histórico como artefacto literario (138)

I

La historia de la conquista de América se asienta sobre los mitos que circulaban en la época. Existió en el siglo XVI, como lo denomina Beatriz Pastor (1983), una "intensa tendencia quimérica y mitómana" entre los españoles que mostraban credulidad y fascinación frente a leyendas fantásticas y mitos fabulosos. Estos relatos provenían de la tradición occidental y asiática y de las tradiciones indígenas que fueron muchas veces malinterpretadas por los europeos que llegaban al continente con afán de acumular riqueza.

Los mitos fundamentales de la conquista del sur se sostuvieron sobre una idea de base: la existencia de una región fabulosa situada sobre la franja equinoccial. La hipótesis de la existencia de esta geografía fantástica se asoció a una teoría cosmográfica muy en boga en la época sobre la distribución de los metales preciosos en el globo terrestre. La necesidad de hallar oro en esas regiones ignotas marcó un impulso fundamental en el proceso de conquista y constituyó uno de los móviles más fuertes, sino tal vez el más importante. La teoría de la distribución de los metales proporcionó una base científica sobre la cual se apoyaron los conquistadores a la hora de emprender las costosas empresas hacia el interior del continente. Sin embargo, los mitos que actuaron como incentivo directo en el proceso de exploración se vincularon estrechamente a leyendas indígenas y europeas, tradiciones históricas y noticias proporcionadas por habitantes y sobrevivientes de expediciones anteriores.

En 1538, el encuentro entre los expedicionarios Benalcázar, Federman y Ximénez de Quesada impulsa la propagación de un mito que encuentra sus orígenes en una ceremonia celebrada por una población chibcha que habitaba a las orillas de la laguna Guatavita y que se conocería posteriormente como El Dorado. La leyenda indígena contaba que esa costumbre databa de la época en que existió en esa zona una cacica adúltera que fue descubierta y castigada públicamente de manera tan feroz que, avergonzada, huyó para arrojarse a las aguas de la laguna. El cacique arrepentido pidió el consejo de los sacerdotes quienes le dijeron que su esposa vivía en un palacio en el fondo de las aguas.

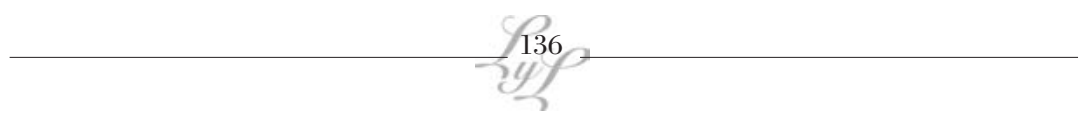


A partir de ese momento, el cacique comenzó a realizar, desnudo y totalmente cubierto de polvo de oro, ofrendas de metales y piedras preciosas a su esposa. El Dorado se convirtió en uno de los objetivos míticos más perseguidos por las ambiciones españolas y, con el paso del tiempo, se transformó en sinónimo de cualquier región dotada de enormes riquezas.

En Historiografía y ficción en la narrativa hispanoamericana, Carmen Perilli señala que la Historia latinoamericana asumió dos formas de expresión: la épica y el mito. El discurso de la épica correspondía a la "historia oficial" escrita por los grupos dominantes de vencedores y transmitida por el sistema cultural y educativo. En los registros llevados a cabo por los cronistas, se construye un modelo de conquista y de conquistador que proporcionó una epopeya al continente colonizado, fortificando la leyenda nacional y legitimando al Estado (1995:39-40). Por su parte, la visión de los vencidos se refugió en la tradición oral, en historias maravillosas como las que dieron origen a El Dorado y que permitieron la conservación de su pasado en el tiempo y el espacio sagrado de la mitología indiana.

Es precisamente este mundo de relatos fantásticos el que permitió la preservación de una memoria que fue mancillada por la violencia europea, negada por los discursos oficiales y que resurge en el siglo XX a través de la ficción literaria.

\section{II}

Cualquier parecido o semejanza entre lo que aparece transcripto aquí y lo correspondiente al renglón de los hechos y de las personas de carne y hueso es pura y casual coincidencia. Algo similar a la historia de esa canción que dice que en un bosque de la China una china se perdió.

Con esta advertencia se abre Crónica de Músicos y diablos, tercera obra del escritor peruano Gregorio Martínez, publicada en 1985 y por la cual recibe el premio IV Bienal de Literatura Gaviota Roja. Como en su primera novela, Canto de sirena (1974), en esta obra Martínez retoma nuevamente el discurso historiográfico colonial como material para su proyecto literario.

Crónica rompe la linealidad de la organización cronológica enunciada en su título para incorporar en el relato una serie de historias que se cuentan simultáneamente a la manera de un contrapunto [1]. En la 
obra entran en conflicto diferentes versiones ficcionalizadas de sucesos históricos que se oponen al "olvido obligatorio" impuesto desde el discurso historiográfico. Cada una de las historias representa el rescate de la memoria popular por sobre la Historia oficial. La univocidad de los discursos de la epopeya y el mito ingresan en la ficción literaria vinculados dialógicamente para enfrentar sus universos ideológicos, generando un modelo semiológico nuevo donde "la escritura lee otra escritura, se lee a sí misma y se construye en una génesis destructiva" (Perilli, 1995:35-36).

En Mito y archivo. Una teoria de la narrativa latinoamericana (2000), Roberto González Echevarría se cuestiona sobre las motivaciones que impulsan a los narradores contemporáneos hacia un retorno a las crónicas de indias y a los textos coloniales en general. A partir del concepto de ficciones de archivo, explica las conexiones entre el conocimiento antropológico y la narrativa latinoamericana.

Las ficciones de archivo son narrativas que siguen buscando la clave de la cultura y la identidad latinoamericana, por lo que caen en la mediación suministrada por el discurso antropológico. Se estructuran como una compleja red intertextual que conforma una piñata de textos dotados de significado cultural: crónicas del descubrimiento y la conquista, diversas ficciones, documentos y personajes históricos, canciones, poesías, informes, mitos y tropos privilegiando el lenguaje de la literatura.

En "La quimera del oro", primer capítulo de la obra, la ficción actualiza el mito de El Dorado y la figura del conquistador como parte del Archivo. Allí Martínez construye una genealogía que rastrea los orígenes hispánicos de una familia de Cahuachi, los Guzmán, hasta llegar a los primeros europeos en América. El autor se convierte, como sostiene González Echevarría, en una especie de antropólogo que busca a través de la escritura literaria el secreto de su propia singularidad. El origen de la familia Guzmán es el origen de toda la costa sur peruana y también el de su mismo autor.

Pedro de Guzmán encarna el arquetipo de conquistador que emprende un viaje en busca de la riqueza que no heredó en España; el héroe histórico que se ubica en el inicio de los tiempos fundacionales de la nación y que la obra cuestiona constantemente a través de su caricaturización. El texto legitima una versión popular de la historia a través de la ridiculización de la voz del poder.

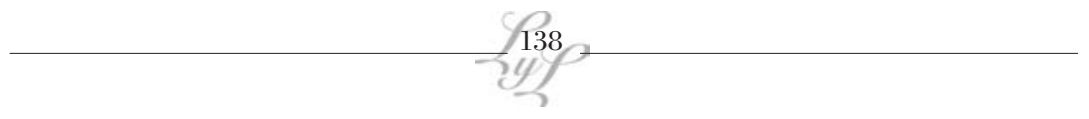


La utilización de la ironía como recurso fundamental del texto pone en evidencia esas tensiones en pugna para finalmente resolverse a favor de la versión de las clases dominadas. Estas tensiones se construyen por medio de un lenguaje irreverente, plagado de imágenes y de recursos estilísticos. Se destacan entre ellos las metáforas, comparaciones, cosificaciones y una abundancia de adjetivaciones barrocas amalgamando derivaciones, duplicaciones y neologismos. Este tratamiento especial del lenguaje configura "el tono" de la obra, permitiendo el desarrollo de la ironía en su máxima expresión.

La llegada de Guzmán a Puerto Caballa marca el inicio de una historia que transforma el espacio y los sujetos que hasta ese momento eran parte de una geografía ignorada por el mundo europeo.

En el texto, el dominio occidental se impone por la "pureza" de la sangre y la "finura" del abolengo del español que se ponen en evidencia en supuestas marcas corporales que funcionan como sinécdoques de la condición de hombre completo que asegura poseer.

El susodicho aparecido aseñaló, para de aquel modo conceder mayor fianza y despejar las turbias murmuraciones, que era un hijodalgo español tangible y de legítima estirpe, y que si quedaban dudas estaba dispuesto, de buen talante, para que cualquier entendido en genealogía le sopesara los compañones con ambas manos. (21)

Esas marcas corporales que posee el personaje se unen a otras que le impone la geografía, convirtiéndose en un sujeto nuevo. El cuerpo del audaz conquistador, apenas recuperado de los estragos de la travesía, es sometido a los esfuerzos propios de la empresa que lleva adelante.

Como lo señala Carmen Perilli, cada personaje tiene una consistencia que le es propia y que define una figura, así como una cierta calidad en cuanto a los valores que se le reconocen, pero, sobre todo, una relación a determinar con el modelo -real o imaginario- que reproduce, sigue y lo transforma (Perilli, 1995:51).

A partir de allí se inicia un proceso de degradación a nivel de la enunciación que es reforzado por los recursos de construcción del enunciado. El personaje se va desdibujando hasta convertirse en una figura "fantasmagórica". Poco a poco, el cuerpo del conquistador sucumbe ante la violencia de un espacio que se le revela y rebela. Finalmente, el objetivo mítico se materializa en el ansiado arribo a Huanuhuanu, lugar positivo de la quimera. 


\section{III}

Llegó descangallado, mejor dicho, hasta su ojete, pero inducido por el instinto de su ambicia mantenía los ojos bien abiertos y la palabra a flor de

labios. (23)

Según Pastor, la emergencia de una conciencia hispanoamericana aparece ligada íntimamente a los procesos de cancelación de los mitos que seguían a la desilusión de aquellos no encontraban lo que se proponían encontrar. El fracaso y el desengaño constituyeron la base sobre la cual se produjo una distancia crítica con respecto a los modelos ideológicos y literarios dominantes que desembocarían en su liquidación.

A medida que avanza la narración, la figura del conquistador pierde su fuerza para darle centralidad a la geografía que, a diferencia de los personajes que transitan por ella, es testigo permanente de todos los sucesos.

Pedro de Guzmán no tuvo ninguna intención de testimoniar para la historia su extravío, pero ahí en el rescoldo del desierto, entre el mar y Cahuachi, quedó para gloria o escarnio de la posteridad, la escritura imborrable de sus pasos. (23)

La imagen de la huella en la arena como metáfora de una escritura devela una clave importante del texto. Es el espacio el que contiene las marcas de esa "otra historia" y es allí donde el cronista va a buscar los datos que necesita.

Como Cristóbal Colón, Pedro de Guzmán comete un error en sus cálculos de navegación. Sin embargo, el personaje reconoce su error, actitud que le permite corregir el rumbo y posibilita la concreción exitosa del viaje.

El fracaso de la empresa del conquistador no radica en la inexistencia del lugar mítico. En contraste con los expedicionarios que fueron tras la búsqueda de El Dorado, Pedro de Guzmán logra encontrar la ubicación exacta de Huanuhuanu. Los derechos otorgados por la corona transforman el espacio, sacándolo de su estado virginal y de leyenda para convertirse en asentamiento poblacional. Lo que antes se ignoraba ahora tiene un lugar en los atlas geográficos, urbanizándose y recibiendo correspondencia.

Sin embargo, como toda quimera, se desvanece rápidamente. El hallazgo del mineral dorado logra demostrar que no se trata de oro puro, la contaminación con mercurio resta su valor, a lo que debemos

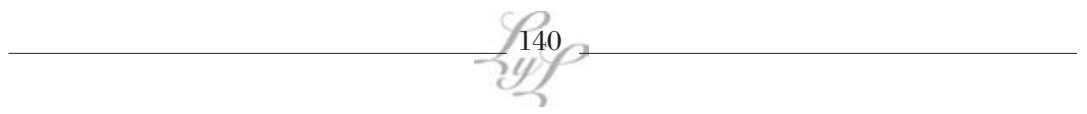


agregar la complicación de un yacimiento pequeño que pronto deja de producir.

La cancelación del mito de Huanuhuanu produce un movimiento inverso, la inmigración se precipita debido a la certeza de que ya no se puede progresar más y esto lleva a los individuos a alejarse del lugar. Este proceso descentralizador dispersa a los descendientes de Pedro de Guzmán que parten en busca de mejores destinos.

\section{IV}

Al igual que Doña Bárbara de Rómulo Gallegos y Los pasos perdidos de Alejo Carpentier, Crónica de músicos y diablos se une a la serie de textos maestros que intentan, desde la ficción, recuperar los documentos del Archivo. Mitos como El Dorado se actualizan en la obra del escritor peruano, quien se apropia de figuras y escrituras del periodo colonial como base para su proyecto literario.

No es en la Historia inscripta en papel donde se esconde la verdad de los hechos. Crónica escucha el murmullo de los mitos populares y el clamor de una geografía que habla desde el lenguaje de los troncos corroídos por la carcoma, las criadillas del carnero y las marcas del desierto entre Puerto Caballa y Cahuachi. Martínez reescribe las páginas borradas de la historia construyéndose a sí mismo como un cronista de otra historia.

\section{Bibliografía}

González Echevarría, Roberto (2000). Mito y archivo. Una teoría de la narrativa latinoamericana. Fondo de Cultura Económica, México.

Martínez, Gregorio (1991). Crónica de músicos y Diablos. Peisa, Lima.

Pastor, Beatriz (1983). El discurso narrativo de la conquista de América. Casa de las Américas, La Habana.

Perilli, Carmen (1995). Historiografía y ficción en la narrativa hispanoamericana. Universidad Nacional de Tucumán, Tucumán.

White, Hyden (2003). El texto histórico como artefacto literario. Paidós, Buenos Aires. 
Gregorio Martínez, cronista de otra historia / Alejandra Huespe

\section{Notas}

[1] Las historias narradas en Crónica son las siguientes: La historia de la familia Guzmán desde sus orígenes coloniales hasta su metamorfosis en los músicos de Cahuachi, la historia de la rebelión del palenque de Huachipa (siglo XVIII) y su aniquilación, la historia de la revuelta popular en Parcona (18 de febrero de 1924) y la historia de la elaboración del pisco por el negro Miguelón Avilés. 